\title{
PENGARUH INTENSITAS ASET TETAP, LEVERAGE, LIKUIDITAS, PERTUMBUHAN PERUSAHAAN DAN UKURAN PERUSAHAAN TERHADAP REVALUASI ASET TETAP PADA PERUSAHAAN MANUFAKTUR SEKTOR INDUSTRI DASAR DAN KIMIA YANG TERDAFTAR DI BURSA EFEK INDONESIA
}

\author{
Herdini Br Sitepu ${ }^{1}$ \\ Evelin R.R. Silalahi ${ }^{2}$ \\ ${ }^{1}$ Program Studi Akuntansi Universitas Katolik Santo Thomas. herdinisitepu01@gmail.com \\ ${ }^{2}$ Dosen Program Studi Akuntansi Universitas Katolik Santo Thomas. evelinsilalahi37@gmail.com
}

\begin{abstract}
Abstrak
Penelitian ini bertujuan untuk mengetahui pengaruh intensitas aset tetap, leverage, likuiditas, pertumbuhan perusahaan dan ukuran perusahaan terhadap revaluasi aset tetap pada perusahaan manufaktur sektor industri dasar dan kimia yang terdaftar di Bursa Efek Indonesia. Teknik pengambilan sampel yang digunakan adalah purposive sampling dengan jumlah sampel sebanyak 96 perusahaan dengan periode penelitian selama 4 tahun dari tahun 2014-2017. Data diperoleh dari Bursa Efek Indonesia melalui website www.idx.co.id.Teknik analisis data yang digunakan adalah analisis regresi logistik. Hasil uji menunjukkan bahwaleverage dan pertumbuhan perusahaan berpengaruh positif dan signifikan terhadap revaluasi aset tetap, intensitas aset tetap berpengaruh negatif dan signifikan terhadap revaluasi aset tetap, likuiditas berpengaruh negatif dan tidak signifikan terhadap revaluasi aset tetap, dan ukuran perusahaan berpengaruh positif dan tidak signifikan terhadap revaluasi aset tetap dan secara bersama-sama variabel intensitas aset tetap, leverage, likuiditas, pertumbuhan perusahaan dan ukuran perusahaan berpengaruh positif dan signifikan terhadap revaluasi aset tetap. Oleh karena itu, penulis menyarankan agar penelitian selanjutnya dapat menambahkan variabel lain serta memperpanjang periode penelitian sehingga dapat melihat kecendrungan yang terjadi dalam jangka panjang sehingga hasil yang diperoleh lebih dapat menggambarkan kondisi yang sesungguhnya selama jangka panjang.
\end{abstract}

Kata Kunci : Revaluasi Aset Tetap, Intensitas Aset Tetap, Leverage, Likuiditas, Pertumbuhan Perusahaan dan Ukuran Perusahaan.

\section{PENDAHULUAN}

Tujuan utama perusahaan adalah memperoleh keuntungan untuk kemakmuran pemilik. Perusahaan perlu mengalokasikan modal dengan teliti untuk mencapai tujuan tersebut. Modal yang cukup mendapat perhatian adalah modal berupa aset tetap yang tersaji dalam laporan keuangan.Aset tetap menjadi salah satu komponen penting dalam menjalankan operasional perusahaan karena perusahaan pada 
umumnyatelah menginvestasikan sebagian kekayaannya pada aset tetap sebagai penggerak kegiatan operasional perusahaan. Sehingga perlakuan akuntansi terhadap aset tetap yang kurang tepat atau tidak sesuai dengan Pernyataan StandarAkuntansi Keuangan akan membawa pengaruh dalam penyajian laporan keuangan.

IAI (Ikatan Akuntan Indonesia) telah mengeluarkan PSAK 16: Aset Tetap sejak proses konvergensi IFRS (International Financial ReportingStandars) pada tahun 2012, sebagai panduan bagi entitas yang ingin melakukan revaluasi aset tetap di Indonesia.Sebelum dikeluarkannya PSAK 16 tahun 2012, aset tetap disajikan berdasarkan nilai perolehan aset dikurangi akumulasi penyusutan dan akumulasi rugi penurunan nilai aset.Namun setelah adanya konvergensi IFRS menyebabkan terjadinya perubahan pada PSAK 16, diantaranya adalah perbedaan pengukuran aset tetap setelah pengakuan awal.Pengukuran setelah pengakuan menurut PSAK No. 16 (IAI, 2018) yaitu "Entitas memilih antara harga perolehan (historical cost) atau revaluasi sebagai kebijakan akuntansinya dan menerapkan kebijakan tersebut terhadap seluruh aset tetap dalam kelas yang sama". Dimana pada revaluasi setelah pengakuan sebagai aset, aset tetap yang nilai wajarnya dapat diukur secara andal harus dicatat pada jumlah revaluasian, yaitu nilai wajar pada tanggal revaluasi dikurangi akumulasi penyusutan dan akumulasi rugi penurunan nilai setelah tanggal revaluasi.

Aset tetap adalah bagian yang sangat penting dalam laporan keuangan. Sehingga penggunaan aset tetap secara efisien akan menentukan kinerja suatu perusahaan.Dimana kebijakan revaluasi aset tetap akan mencerminkan keadaan yang sebenarnya dari aset tetap, karena revaluasi akan mencatat nilai dari aset tetap menggunakan nilai pasar, sehingga nilai aset tetap menjadi relevan sebab nilai aset tetap yang disajikan dalam laporan keuangan adalah nilai aset tetap saat ini, bukan nilai aset tetap saat perolehan.

Penelitian mengenai revaluasi aset tetap telah dilakukan oleh beberapa peneliti sebelumnya.Penelitian sebelumnya menunjukkan beberapa faktor yang terbukti berpengaruh dalam pemilihan revaluasi aset tetap.Tay(2009) pada penelitiannya di Selandia Barumembuktikan bahwa fixed asset intensity dan firm size berpengaruh signifikan terhadap perusahaan dalammelakukan revaluasi aset tetap, sedangkan leverage, liquidity, dan market to book ratio berpengaruhsignifikan negatif terhadap kebijakan revaluasi asettetap.Sebaliknya beberapa peneliti menemukan hal berbeda dimana faktor-faktor tersebut terbukti 
berpengaruh negatif terhadap revaluasi aset tetap, seperti yang ditemukan oleh Seng dan Su (2010) yang hanya berhasil membuktikan firm size memiliki hubungan yang signifikan dengankebijakan revaluasi, namun tidak menemukanpengaruh hubungan antara proksi dari variabel debt contracts dan proksi dari variabel information asymmetry terhadap kebijakan revaluasi aset tetap.

Berdasarkan uraian latar belakang masalah diatas, maka dapat di rumuskan masalah penelitian sebagai berikut: "apakah Intensitas Aset Tetap, Leverage, Likuiditas, Pertumbuhan Perusahaan, dan Ukuran Perusahaan berpengaruh positif signifikan terhadap Revaluasi Aset Tetap pada Perusahaan Manufaktur Sektor Industri Dasar dan Kimia yang Terdaftar di Bursa Efek Indonesia?"

\section{TINJAUAN PUSTAKA}

\section{Teori Akuntansi Positif}

Teori akuntansi positif berupaya menjelaskan sebuah proses, yangmenggunakan kemampuan, pemahaman, dan pengetahuan akuntansi sertapenggunaan kebijakan akuntansi yang paling sesuai untuk menghadapi kondisi tertentu dimasa mendatang.Teori akuntansi positif dirumuskan sebagai suatu susunan konsep, defenisi, dan dalil yang menyajikan secara sistematis gambaran fenomena akuntansi, serta menjelaskan hubungan antar variabel dalam struktur akuntansi, dengan maksud untuk teori akuntansi positif memprediksi fenomena yang muncul baik fenomena sosial dan ekonomi (Harahap, 2018:2).

\section{Teori Agensi}

Teori keagenan menjelaskan pola hubungan antara principal dan agen. Hubungan keagenan merupakan sebagai kontrak dimana satu orang atau lebih principal terlibat dengan orang lain (agen) untuk melakukan beberapa layanan atas nama mereka yang mendelegasikan beberapa kewenangan membuat keputusan kepada agen. Menurut Sartono (2016) bentuk hubungan keagenan itu biasanya terjadi antara manajer dan pemegang saham (shareholders) dan antara debtholders dan stakeholders.

\section{Pengertian Aset Tetap}

Pada dasarnya perusahaan dalam mencapai tujuan-tujuan ekonominya menggunakan sumber daya yang ada salah satunya dalam menghasilkan suatu produk. Agar dapat menghasilkan produk untuk memenuhi tujuannya, setiap perusahaan harus memiliki aset. Aset yang 
dimiliki perusahaan dapat dikelompokkan ke dalam beberapa kelompok sesuai dengan kriteria yang dimiliki, mulai dari aset lancar, aset tidak berwujud, hingga aset berwujud.Menurut Sumarsan (2018:57) aset tetap (fixed assets) merupakan aset yang dibeli perusahaan dengan nilai yang relatif tinggi untuk digunakan dalam operasional perusahaan untuk jangka waktu yang lebih dari satu tahun. Kriteria dari aset tetap:

1. Digunakan untuk operasional perusahaan

2. Memiliki masa manfaat lebih dari satu tahun

3. Memiliki nilai yang relatif tinggi

\section{Revaluasi Aset Tetap}

Dalam PSAK 16 Aset Tetap dalam pengukuran setelah pengakuan aset tetap berbunyi "Entitas dapat memilih model biaya atau model revaluasi sebagai kebijakan akuntansinya dan menerapkan kebijakan tersebut terhadap aset tetap dalam kelas yang sama".Dimana harga perolehan (biaya) adalah penilaianaset yang didasarkan pada jumlah pengorbanan ekonomis yang dilakukanperusahaan untuk memperoleh aset tetap tertentu sampai aset tetap tersebutsiap digunakan. Itu berarti nilai aset yang disajikan dalam laporan keuanganadalah jumlah rupiah historis pada saat memperoleh aset tetap tersebutdikurangi dengan akumulasi penyusutannya (jika ada) (Rudianto, 2012:257).

Namun penggunaan harga perolehan membuat nilai aset tetap menjadi tidak relevan karena tidak menunjukkan nilai terkini dari aset tetap yang dimiliki oleh perusahaan sehingga Ikatan Akuntan Indonesia (IAI) mengeluarkan PSAK 16: Aset Tetap yang mana menjadi panduan bagi entitas untuk memilih menggunakan biaya atau revaluasi sebagai pengukuran aset tetap dari suatu entitas.Revaluasi aset tetap adalah penyesuaian harga atau nilai perolehan harta atau aktiva tetap berwujud yang dimiliki dan digunakan dalam perusahaan berkenaan dengan perubahan nilai tukar mata uang. Menurut Sumarsan (2018:72) revaluasi merupakan penilaian kembali aset tetap suatu perusahaan yang diakibatkan adanya kenaikan nilai aset tetap tersebut di pasaran atau karena rendahnya nilai aset tetap dalam laporan keuangan perusahaan yang disebabkan oleh devaluasi atau sebab lain, sehingga nilai aset tetap dalam laporan keuangan tidak lagi mencerminkan nilai yang sewajarnya.

Nilai wajar tanah, bangunan serta aset lainnya biasanya ditentukan melalui penilaian yang dilakukan oleh jasa penilai (Appraisal) yang memiliki kualifikasi profesional berdasarkan bukti pasar dan berdasarkan kepada fakta-fakta yang objektif, jujur dan harus memiliki relevansi 
dengan menggunakan metode parameter serta prinsip-prinsip yang tidak melanggar norma dan hukum yang berlaku. Dimana appraisal adalah sebuah proses pekerjaan seorang yang ahli di bidangnya dalam hal memberikan sebuah penilaian berupa estimasi atau perkiraan (asumsi) atas nilai sebuah objek. Orang yang melakukan appraisal tersebut sering disebut sebagai appraiser.

Dan jika suatu aset tetap direvaluasi, maka akumulasi penyusutan pada tanggal revaluasi diperlakukan dengan salah satu cara berikut ini:

1. Disajikan kembali secara porposional dengan perubahan dalam jumlah tercatat bruto aset sehingga jumlah tercatat aset setelah revaluasi sama dengan jumlah revaluasiannya. Metode ini sering digunakan apabila aset direvaluasi dengan cara memberi indeks untuk menentukan biaya pengganti yang telah disusutkan.

2. Dieliminasi terhadap jumlah tercatat bruto aset dan jumlah tercatatneto setelah eliminasi disajikan kembali sebesar jumlah revaluasian dari aset tersebut. Metode ini sering digunakan untuk bangunan.

Dan ketika revaluasi menunjukkan angka positif, dimana nilai buku aset tetap terapresiasi akibat penyesuaian terhadap nilai pasar, kenaikan nilai tersebut tidak boleh dicatat dalam laporan laba rugi (Income Statement). Kenaikan tersebut harus dikreditkan di akun khusus dalam laporan ekuitas. Nama akun tersebut adalah Revaluation Surplus. Didalam akun ini terkandung segala kenaikan tiap nilai aset tetap akibat revaluasi sampai aset tetap tersebut dijual, disumbangkan atau dibuang.Namun sebaliknya jika terjadi penurunan nilai (impairment), penurunan tersebut harus didebit di akun Revaluation Surplus. Jika penurunan atau kerugiannya melebihi nilai surplus, maka harus dicatat pada akun impairment loss. Dan nilai aset tetap yang sudah direvaluasi kemudian menjadi nilai dasar baru untuk didepresiasi. Depresiasi masih terus dilakukan pada aset tetap dengan nilai buku yang baru, di umur ekonomis yang masih tersisa.

\section{Intensitas Aset Tetap}

Intensitas adalah ukuran seberapa banyak (besar atau kecil) penggunaan dari suatu aset. Intensitas aset tetap menunjukkan jumlah aset tetap yang dimliki oleh perusahaan dibandingkan dengan total aset perusahaan dan menggambarkan banyaknya investasi perusahaan terhadap aset tetap perusahaan. Menurut Syamsudin (2007:9) intensitas aset tetap adalah penentuan berapa besar alokasi dana untuk masing-masing komponen aktiva, baik dalam aktiva lancar maupun dalam aktiva tetap. 
Dimana kepemilikan aset tetap yang tinggi akan menghasilkan beban depresiasi atas aset yang besar pula, sehingga laba perusahaan akan berkurang akibat adanya jumlah aset tetap yang besar. Sehingga tingginya jumlah aset yang ada di perusahaan akan meningkatkan agresivitas pajak perusahaan dan mempengaruhi beban pajak perusahaan karena adanya beban depresiasi yang melekat pada aset tetap. Semakin tinggi intensitas aset tetap maka semakin besar proporsi aset tetap yang ada di dalam perusahaan dibandingkan dengan aset lainnya. Intensitas aset tetap diperoleh dengan membandingkan total aset tetap dan total aset dan intensitas aset tetap (fixed aset intensity), digunakan sebagai pengukur informasi asimetri. Dimana dalam penelitian ini intensitas diukur dengan rumus :

\section{Leverage}

$$
\text { Fixed Assets Intensity }=\frac{\text { Total Fixed Asset }}{\text { Total Asset }} \times 100 \%
$$

Menurut Sartono (2016:120) leverage adalah sebagai berikut :Financial leverage menunjukkan proporsi atas penggunaan utang untuk membiayai investasinya.Perusahaan yang tidak mempunyai leverage berarti menggunakan modal sendiri 100\%. Penggunaan utang itu sendiri bagi perusahaan mengandung tiga dimensi :

1. Pemberi kredit akan menitikberatkan pada besarnya jaminan atas kredit yang diberikan.

2. Dengan menggunakan utang maka apabila perusahaan mendapatkan keuntungan yang lebuh besar dari beban tetapnya maka pemilik perusahaan keuntungannya akan meningkat.

3. Dengan menggunakan utang maka pemilik memperoleh dana dan tidak kehilangan pengendalian perusahaan.

Dimana dalam penelitian ini leverage diukur dengan rumus :

\section{Likuiditas}

$$
\text { Debt To Equity Ratio }=\frac{\text { Total Liabilitas }}{\text { Total Equity }} \times 100 \%
$$

Menurut Sartono (2016:116) rasio likuiditas adalah :

Likuiditas perusahaan,menunjukkan kemampuan untuk membayar kewajiban finansial jangka pendek tepat pada waktunya.Likuditas perusahaan ditunjukkan oleh besar kecilnya aktiva lancar yang mudah untuk diubah menjadi kas yang meliputi kas,surat berharga,piutang, dan persediaan. Tingkat likuiditas perusahaan dapat diukur melalui current ratio. Current ratio dihitung dengan cara aktiva lancar dibagi hutang 
lancar. Rasio ini menunjukkan sejauh mana aktiva lancar dengan hutang lancar menutupi kewajiban-kewajiban lancar. Semakin besar perbandingan aktiva lancar dengan hutang lancar berarti semakin tinggi kemampuan perusahaan menutupi kewajiban jangka pendeknya. Dimana dalam penelitian ini likuiditas diukur dengan rumus :

\section{Pertumbuhan perusahaan}

$$
\text { Current Ratio }=\frac{\text { Current Asset }}{\text { Current Liability }} \times 100 \%
$$

Pertumbuhanadalah perubahan (penurunan atau peningkatan) total aktiva yang dimiliki oleh perusahaan. Menurut Murti (2011:64) rasio pertumbuhan adalah mengukur seberapa jauh kemampuan perusahaan mempertahankan posisi ekonominya didalam keadaan ekonomi pada umumnya dan didalam industri dimana perusahaan itu termasuk. Rasio pertumbuhan dicerminkan melalui data penjualan, pendapatan bersih, perolehan setiap saham (earning per shares), dividen setiap saham, ratarata harga pasar setiap saham dan nilai buku setiap saham. Perhitungan pertumbuhan perusahaan dilandaskan pada data satu periode tertentu, misalkan lima tahun berurutan. Pertumbuhan tersebut dihitung dengan cara :

1. Bagi angka tahun terakhir ini periode tertentu itu dengan angka tahunan pertama dari periode yang bersangkutan. Proses ini menghasilakn suatu jumlah faktor bunga majemuk (compound sum of interest factor).

2. Cari dalam tabel bunga majemuk untuk mendapatkan persentasi pertumbuhan dan diwujudkan oleh ratio tertentu.

Dimana dalam penelitian ini pertumbuhan perusahaan diukur dengan rumus :

$$
\text { Pertumbuhan Perusahaan }=\frac{(\text { total aset tahun } \mathrm{n}-\text { total aset tahun } \mathrm{n}-1)}{\text { total aset tahun } \mathrm{n}-1}
$$

\section{Ukuran Perusahaan}

Ukuran perusahaan merupakan suatu skala yang menentukan besar kecilnya suatu perusahaan. Ukuran perusahaan mencerminkan seberapa besar total aset yang digunakan dalam perusahaan. Menurut Riyanto (2001:299) ukuran perusahaan merupakan perusahanan yang memiliki saham yang besar, dan masing-masing penambahan lembar sahamnya hanya mempengaruhi sebagian kecil pada kemungkinan hilang kontrol dari pihak dominan kepada perusahaan yang terkait.Sehingga semakin besar 
ukuran perusahaan, semakin besar dana yang dikelola dan semakin kompleks pengelolaannya.

Perusahaan besar cenderung mendapat perhatian yang lebih oleh masyarakat. Dengan demikian, perusahaan dituntut untuk menjaga stabilitas perusahaan dan meningkatkan kreadibilitasnya dalam menyajikan laporan keuangan karena perusahaan besar memiliki basis pengguna laporan keuangan yang lebih besar. Untuk menjaga stabilitas dan kreadibilitasnya, perusahaan tentu saja akan berusaha menjaga dan terus meningkatkan kinerjanya. Dimana dalam penelitian ini ukuran perusahaan diukur dengan rumus :

$$
\text { Size }=\text { Ln Total Assets }
$$

\section{Pengaruh Intensitas Aset Tetap terhadap Revaluasi Aset Tetap}

Menurut Weston dan Brigham (2005:175) struktur aset adalah perimbangan atau perbandingan antara aset tetap dan total aset. Aset tetap digunakan untuk produksi barang dan jasa maupun untuk mendukung operasional perusahaan. Dimana menurut Sartono (2016:248) perusahaan dengan tingkat intensitas aset tetap yang tinggi akan memilih menggunakan revaluasi aset tetap sebagai metode pengukuran dan pengakuan aset tetapnya untuk mencerminkan nilai aset yang sesungguhnya, dan sebaliknya perusahaan dengan tingkat intensitas aset tetap yang rendah cenderung tidak memilih menggunakan revaluasi aset tetap sebagai metode pengukuran dan pengakuan aset tetapnya.Karena perusahaan yang memiliki aset tetap dalam jumlah besar dapat menggunakan utang dalam jumlah yang besar hal ini disebabkan karena dari skalanya perusahaan besar akan lebih mudah mendapatkan akses ke sumber dana dibandingkan dengan perusahaan kecil. Sehingga modal yang tertanam dalam bentuk aset tetap jumlahnya cukup besar sehingga menjadi item laporan keuangan yang mendapat perhatian lebih besar dari principal.

\section{Pengaruh Leverage terhadap Revaluasi Aset Tetap}

Leverage merupakan rasio yang digunakan untuk mengukur sejauh mana aset perusahaan dibiayai dengan hutang. Artinya berapa besar utang yang ditanggung perusahaan dibandingkan dengan aset. Leverage digunakan untuk mengukur kemampuan perusahaan untuk membayar seluruh kewajibannya, baik jangka pendek maupun jangka panjang apabila perusahaan dilikuidasi (Sartono, 2016:121).Menurut Kasmir (2011:113) perusahaan dengan tingkat leverage yang tinggi akan memilih untuk menggunakan revaluasi aset tetap sebagai metode pengukuran dan 
pengakuan aset tetapnya, dan sebaliknya perusahaan dengan tingkat leverage yang rendah memilih untuk tidak menggunakan revaluasi aset tetap sebagai metode pengukuran aset tetap perusahaannya. Karena rasio solvabilitas atau leverage ratio merupakan ratio yang digunakan untuk mengukur sejauh mana aktiva perusahaan dibiayai dengan utang. Artinya berapa besar beban utang yang ditanggung perusahaan dibandingkan dengan aktivanya.

\section{Pengaruh Likuiditas terhadap Revaluasi Aset Tetap}

Menurut Sartono (2016:116) likuiditas perusahaan menunjukkan kemampuan untuk membayar kewajiban finansial jangka pendek tepat pada waktunya. Dimana likuiditas perusahaan ditunjukkan oleh besar kecilnya aktiva lancar yaitu aktiva yang mudah untuk diubah menjadi kas yang meliputi kas, surat berharga, piutang, dan persediaan. Tergantung pada tingkat likuiditas, perusahaan mungkin memutuskan untuk melakukan revaluasi atau tidak terhadap aset tetap. Hal ini karena kebijakan revaluasi dapat menawarkan bantuan dengan memberikan informasi lebih terhadap jumlah uang yang berasal dari penjualan aset dan dengan demikian meningkatkan kapasitas pinjaman dari perusahaan.Menurut Kasmir (2011:110) perusahaan dengan tingkat likuiditas yang rendah akan memilih untuk menggunakan revaluasi aset tetap sebagai metode pengukuran dan pengakuan aset tetap perusahaannya, daripada perusahaan dengan tingkat likuiditas yang tinggi memilih untuk tidak menggunakan revaluasi aset tetap. Rasio likuiditas berpengaruh terhadap kebijakan perusahaan dalam melakukan atau tidak melakukan revaluasi aset tetap.

\section{Pengaruh Pertumbuhan Perusahaan terhadap Revaluasi Aset Tetap}

Menurut Murti (2011:64) rasio pertumbuhan adalah mengukur seberapa jauh kemampuan perusahaan mempertahankan posisi ekonominya didalam keadaan ekonomi pada umumnya dan didalam industri dimana perusahaan itu termasuk. Menurut Sartono (2016:248) perusahaan dengan tingkat pertumbuhan yang tinggi akan memilih untuk menggunakan revaluasi aset tetap sebagai metode pengukuran dan pengakuan aset tetap perusahannya, sedangkan perusahaan dengan tingkat pertumbuhan yang rendah memilih untuk tidak menggunakan revaluasi aset tetap sebagai metode pengukuran dan pengakuan aset tetap perusahaannya. Karena semakin cepat pertumbuhan perusahaan maka semakin besar kebutuhan dana untuk ekspansi. Semakin besar kebutuhan 
untuk pembiayaan mendatang maka semakin besar keinginan perusahaan untuk menahan laba.

\section{Pengaruh Ukuran Perusahaan terhadap Revaluasi Aset Tetap}

Menurut Riyanto (2001:299) ukuran perusahaan merupakan perusahanan yang memiliki saham yang besar, dan masing-masing penambahan lembar sahamnya hanya mempengaruhi sebagian kecil pada kemungkinan hilang kontrol dari pihak dominan kepada perusahaan yang terkait. Menurut Sartono (2016:249) perusahaan dengan ukuran besar kemungkinan akan memilih untuk melakukan dan menggunakan revaluasi sebagai metode pengukuran dan pengakuan aset tetap perusahaannya daripada perusahaan dengan ukuran kecil. Karena perusahaan besar yang sudah well-established akan lebih mudah memperoleh modal di pasar modal dibanding dengan perusahaan kecil.

\section{Kerangka Berpikir}

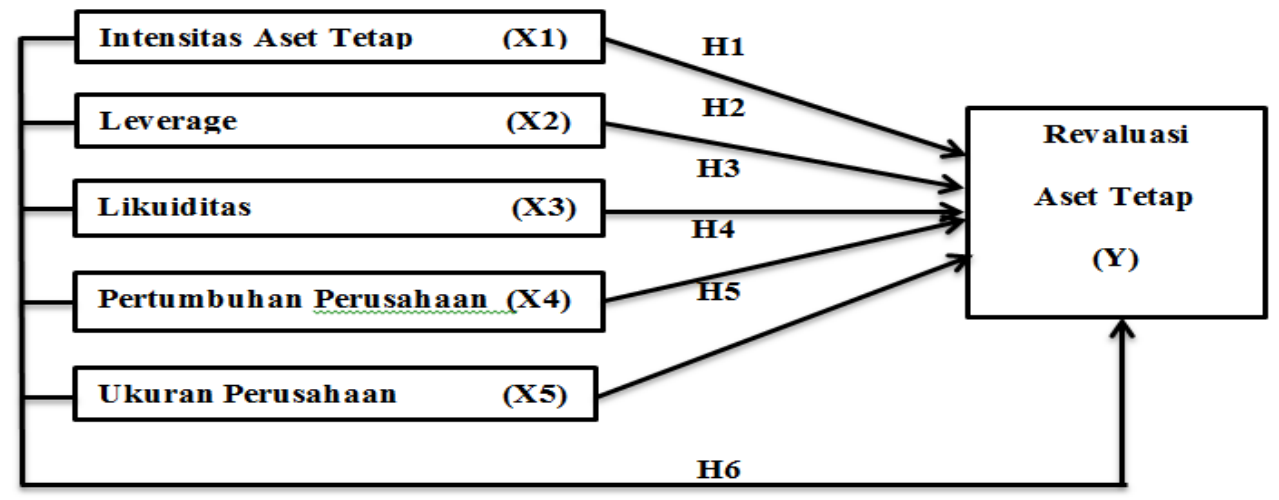

\section{Gambar 1 Kerangka Konseptual}

\section{Hipotesis}

Hipotesis merupakan jawaban sementara atas masalah yang dirumuskan dimana kebenarannya masih harus di buktikan. Berdasarkan landasan teori, maka hipotesis dalam penelitian ini adalah sebagai berikut :

H1 : Probabilitas kemungkinan intensitas aset tetap berpengaruh positif dan signifikan terhadap revaluasi aset tetap pada perusahaan manufaktur sektor industri dasar dan kimia yang terdaftar di bursa efek indonesia.

H2 : Probabilitas kemungkinan leverage berpengaruh positif dan signifikan terhadap revaluasi aset tetap pada perusahaan 
manufaktur sektor industri dasar dan kimia yang terdaftar di bursa efek indonesia.

H3 : Probabilitas kemungkinan likuiditas berpengaruh negatif dan signifikan terhadap revaluasi aset tetap pada perusahaan manufaktur sektor industri dasar dan kimia yang terdaftar di bursa efek indonesia

H4 : Probabilitas kemungkinan pertumbuhan perusahaan berpengaruh positif dan signifikan terhadap revaluasi aset tetap pada perusahaan manufaktur sektor industri dasar dan kimia yang terdaftar di bursa efek indonesia

H5 : Probabilitas kemungkinan ukuran perusahaan berpengaruh positif dan signifikan terhadap revaluasi aset tetap pada perusahaan manufaktur sektor industri dasar dan kimia yang terdaftar di bursa efek indonesia

H6: Probabilitas kemungkinan intensitas aset tetap, leverage, likuiditas, pertumbuhan perusahaan dan ukuran perusahaan berpengaruh positif dan signifikan terhadap revaluasi aset tetap pada perusahaan manufaktur sektor industri dasar dan kimia yang terdaftar di bursa efek indonesia.

\section{METODE PENELITIAN}

\section{Populasi dan Sampel}

Populasi adalah sekelompok entitas yang lengkap yang dapat berupa orang, kejadian atau benda yang mempunyai karakteristik tertentu, yang berada dalam suatu wilayah dan memenuhi syarat-syarat tertentu yang berkaitan dengan masalah penelitian. Populasi dalam penelitian ini adalah perusahaan manufaktur sektor industri dasar dan kimia yang terdaftar di BEI pada periode tahun 2014-2017.

Teknik pengambilan sampel digunakan dalam penelitian menggunakan teknik purposive sampling, yaitu teknik pengambilan sampel dengan menggunakan kriteria (pertimbangan) tertentu.Adapun kriteria penarikan sampel yang digunakan adalah sebagai berikut:

1. Perusahaan Manufaktur sektor industri dasar dan kimia yang terdaftar di Bursa Efek Indonesia pada tahun 2014-2017.

2. Perusahaan menerbitkan laporan keuangan selama periode penelitian dan menyertakan laporan keuangan yang telah diaudit oleh Auditor Independen. 
3. Selama periode penelitian, perusahaan tidak mengalami delisting dari Bursa Efek Indonesia.

4. Mata uang yang digunakan dalam laporan keuangan adalah mata uang Rupiah.

5. Perusahaan yang tidak memiliki kelengkapan data intensitas aset tetap, leverage, likuiditas, pertumbuhan perusahaan dan ukuran perusahaan.

\section{Teknik Pengumpulan Data}

Untuk mendapatkan data yang sesuai dengan perumusan masalah yang telah dikemukakan, maka digunakan data sekunder dengan teknik dokumentasi dan studi pustaka.Teknik dokumentasi ini dilakukan dengan mengumpulkan data yang diperoleh dari perusahaan yang sudah diolah sebelumnya berupa laporan tahunan yang terdapat di Bursa Efek Indonesia (BEI) tahun 2014-2017.

\section{Teknik Analisis Data}

Pengujian hipotesis dilakukan dengan menggunakan regresi logistik karena variabel dependen (Y) diukur dengan variabel dummy dan variabel independen (X) berupa variabel kontinyu maupun variabel kategorial. Dimana dalam penggunaan metode regresi logistic tidak perlu adanya uji asumsi klasik pada variabel bebasnya (Ghozali, 2018:178). Teknik analisis data yang digunakan dalam penelitian ini adalah analisis kuantitatif yaitu pemrosesan dan manipulasi data mentah mengenai informasi yang bermanfaat karena analisis data merupakan suatu proses penyederhanaan data ke dalam bentuk yang mudah di baca dan diinterpretasikan. Dimana model regresi logistik yang digunakan untuk menguji hipotesis penelitian ini adalah sebagai berikut :

$$
\operatorname{Ln} \frac{A R}{1-A R}=\alpha+\beta_{1} \mathrm{X}_{1}+\beta_{2} \mathrm{X}_{2}+\beta_{3} \mathrm{X}_{3}+\beta_{4} \mathrm{X}_{4}+\beta_{5} \mathrm{X}_{5}+\mathrm{e}
$$

Keterangan:

Ln $\frac{A R}{1-A R}=$ Simbol yang menunjukkan probabilitas revaluasi (kategori 1 jika revaluasi, 0 jika tidak revaluasi)

AR : Probabilitas revaluasi 1-AR : Probabilitas tidak revaluasi

$\alpha \quad$ : Konstanta.

$\beta 1-\beta 5$ : Koefisien regresi.

$\mathrm{X}_{1}$ : Proporsi jumlah aset tetap $\quad \mathrm{X}_{2} \quad$ : Tingkat hutang perusahaan

$\mathrm{X}_{3}$ : Likuiditas

$\mathrm{X}_{5}$ : Ukuran perusahaan

$\mathrm{X}_{4} \quad$ : pertumbuhan perusahaan

E : Residual error. 


\section{HASIL PENELITIAN DAN PEMBAHASAN}

\section{Statistik Deskriptif}

Statistik deskriptif merupakan gambaran atau deskriptif suatu data yang dilihat dari jumlah nilai rata-rata (mean), standar deviasi, varian, maksimun, minimum, sum, range, kurtosis dan skewness (kemencengan distribusi). Standar deviasi, nilai maksimum, dan nilai minimum menggambarkan persebaran variabel yang bersifat metrik, sedangkan variabel non-metrik digambarkan dengan distribusi frekuensi variabel. Adapun hasil uji statistik deskriptif untuk penelitian ini dapat dilihat sebagai berikut :

Tabel 1 Analisis Frekuensi Variabel Revaluasi Aset Tetap

\begin{tabular}{|c|c|c|c|c|c|}
\hline \multicolumn{6}{|c|}{ REVALUASI } \\
\hline & & Frequency & Percent & Valid Percent & $\begin{array}{c}\text { Cumulative } \\
\text { Percent }\end{array}$ \\
\hline \multirow[t]{3}{*}{ Valid } & TIDAK REVALUASI & 74 & 77.1 & 77.1 & 77.1 \\
\hline & REVALUASI & 22 & 22.9 & 22.9 & 100.0 \\
\hline & Total & 96 & 100.0 & 100.0 & \\
\hline
\end{tabular}

Sumber : Hasil Output SPSS

Hasil analisis frekuensi pada tabel 4.8 menunjukkan nilai observasi (N) adalah 96 perusahaan. Perusahaan dengan skor 1 merupakan kategori perusahaan yang memilih untuk melakukan revaluasi aset tetap, sedangkan perusahaan dengan skor 0 adalah kategori perusahaan yang tidak memilih untuk melakukan revaluasi aset tetap. Hanya 22,9 \% dari total sampel perusahaan yang melakukan revaluasi aset tetap yaitu sebanyak 22 perusahaan. Sedangkan 74 perusahaan sisa lainnya tidak menggunakan revaluasi aset tetap yaitu sebesar $77,1 \%$.

\section{Tabel 2 Statistik Deskriptif}

\begin{tabular}{|c|c|c|c|c|c|}
\hline \multicolumn{6}{|c|}{ Descriptive Statistics } \\
\hline & $\mathrm{N}$ & Minimum & Maximum & Mean & Std. Deviation \\
\hline INTENSITA ASET TETAP & 96 & .06552 & .94725 & .4920080 & .20164199 \\
\hline LEVERAGE & 96 & .16031 & 8.70554 & 1.5391972 & 1.80752861 \\
\hline LIKUIDITAS & 96 & .08918 & 8.08913 & 1.7787282 & 1.38578952 \\
\hline $\begin{array}{l}\text { PERTUMBUHAN } \\
\text { PERUSAHAAN }\end{array}$ & 96 & .00011 & 1.43777 & .1326533 & .26223535 \\
\hline UKURAN PERUSAHAAN & 96 & 15.84998 & 24.61434 & 21.1211042 & 1.72586071 \\
\hline Valid N (listwise) & 96 & & & & \\
\hline
\end{tabular}

Sumber : Hasil Output SPSS 
Berdasarkan tabel 2 dapat diperjelas maknanya sebagai berikut:

1. Variabel intensitas aset tetap memiliki nilai minimum 0,06552 , nilai maksimum 0,94725, mean (nilai rata-rata) 0,4920080, dan Standart Deviation (simpangan baku ) variabel ini adalah 0,20164199.

2. Variabel leverage memiliki nilai minimum 0.16031, nilai maksimum 8,70554 , mean nilai rata-rata) 1,5391972 , dan Standart Deviation (simpangan baku ) variabel ini adalah 1,80752861.

3. Variabellikuiditasmemiliki nilai minimum 0,08918, nilai maksimum 8,08913, mean (nilai rata-rata) 1,7787282, dan Standart Deviation (simpangan baku ) variabel ini adalah 1,38578952.

4. Variabel pertumbuhan perusahaan memiliki nilai minimum $0, .00011$, nilai maksimum 1,43777, mean (nilai rata-rata) 0,1326533 , dan Standart Deviation (simpangan baku ) variabel ini adalah 0,26223535.

5. Variabel ukuran perusahaan memiliki nilai minimum 15,84998 , nilai maksimum 24,61434, mean (nilai rata-rata) 21,1211042, dan Standart Deviation (simpangan baku ) variabel ini adalah 1,72586071.

\section{Hasil Uji Keseluruhan Model (Overall model Fit)}

Setelah melakukan pengujian deskriptif, langkah selanjutnya adalah melakukan pengujian keseluruhan model. Menurut Gozali (2018:333) untuk menganalisis hasil output data dari regresi logistik dilakukan dengan menggunakan penilaian model fit.

Tabel 3 Hasil Uji Overall Fit Model -2 Log Likelihood Awal Iteration History ${ }^{\mathrm{a}, \mathrm{b}, \mathrm{c}}$

\begin{tabular}{|ll|r|r|}
\hline & & \multicolumn{2}{|c|}{ Coefficients } \\
\cline { 4 - 4 } Iteration & -2 Log likelihood & \multicolumn{2}{|c|}{ Constant } \\
\hline Step 0 & 1 & 103.639 & -1.083 \\
& 2 & 103.348 & -1.209 \\
& 3 & 103.347 & -1.213 \\
& 4 & 103.347 & -1.213 \\
\hline
\end{tabular}

Sumber : Hasil Output SPSS 
Tabel 4 Hasil Uji Overall Fit Model -2 Likelihood Akhir

\begin{tabular}{|c|c|c|c|c|c|c|c|c|}
\hline \multicolumn{9}{|c|}{ Iteration History $y^{a, b, c, d}$} \\
\hline \multirow{2}{*}{\multicolumn{2}{|c|}{ Iteration }} & \multirow[b]{2}{*}{-2 Log likelihood } & \multicolumn{6}{|c|}{ Coefficients } \\
\hline & & & Constant & $\mathrm{X} 1$ & $\mathrm{X} 2$ & $\mathrm{X} 3$ & $\mathrm{X} 4$ & $\mathrm{x} 5$ \\
\hline \multirow{6}{*}{$\begin{array}{l}\text { Step } \\
1\end{array}$} & & 82.614 & -3.805 & -1.582 & 354 & -.007 & 1.313 & .132 \\
\hline & 2 & 78.548 & -6.415 & -3.029 & .408 & -.088 & 1.931 & .271 \\
\hline & 3 & 78.112 & -7.929 & -3.690 & .412 & -.166 & 2.230 & .356 \\
\hline & 4 & 78.101 & -8.232 & -3.778 & .412 & -.188 & 2.286 & .373 \\
\hline & 5 & 78.100 & -8.241 & -3.780 & .412 & -.189 & 2.287 & .373 \\
\hline & 6 & 78.100 & -8.241 & -3.780 & .412 & -.189 & 2.287 & .373 \\
\hline \multicolumn{9}{|c|}{ a. Method: Enter } \\
\hline \multicolumn{9}{|c|}{ b. Constant is included in the model. } \\
\hline \multicolumn{9}{|c|}{ c. Initial -2 Log Likelihood: 103.347} \\
\hline \multicolumn{9}{|c|}{$\begin{array}{l}\text { d. Estimation terminated at iteration number } 6 \text { because parameter estimates changed by less } \\
\text { than } .001 \text {. }\end{array}$} \\
\hline
\end{tabular}

Berdasarkan tabel 3 dan tabel 4, diperoleh informasi bahwa pengujian dilakukan dengan membandingkan nilai antara -2 Log Likehood $(-2 \mathrm{LL})$ awal (Block Number $=0$ ) dengan nilai -2 Log Likehood (-2LL) akhir (Block Number= 1). Nilai -2LL awal adalah103,347. Setelah dimasukkan kelima variabel independen, maka nilai -2LL akhir mengalami penurunan menjadi 78,100, maka dengan penurunan -2 Log Likehood ini menunjukkan model regresi yang lebih baik atau dengan kata lain model yang dihipotesiskan fit dengan data.

\section{Hasil Uji Kelayakan Model Regresi}

Kelayakan model regresi dinilai dengan menggunakan Hosmer and Lemesshow's Goodness of Fit Test. Model dikatakan mampu memprediksi nilai observasi karena cocok dengan data observasinya apabila Nilai Hosmer And Lemeshow's Goodness Of Fit Test $>0,05$.

Tabel 5 Hasil Uji Hosmer And Lemeshow Test And Lemeshow's Goodness Of Fit Test

Hosmer and Lemeshow Test

\begin{tabular}{|c|c|c|c|}
\hline Step & Chi-square & df & Sig. \\
\hline 1 & 4.969 & 8 & .761 \\
\hline
\end{tabular}

Sumber : Hasil Output SPSS 
Dari tampilan tabel 5Hosmer and Lemesshow's di atas terlihat bahwa besarnya nilai statistik Hosmer and Lemesshow's Goodness of Fit test sebesar 4,969 dengan probabilitas signifikansi 0,761 di mana 0,761>0,05. Hal ini berarti model regresi yang dipergunakan dalam penelitian ini layak dipakai untuk analisis selanjutnya, karena tidak ada perbedaan yang nyata antara klasifikasi yang diprediksi dan klasifikasi yang diamati.

\section{Hasil Uji Koefisien Determinasi (Negelkerke R. Square)}

Untuk mengetahui seberapa besar variabel intensitas aset tetap, leverage, likuiditas, pertumbuhan perusahaan dan ukuran perusahaan mempengaruhi menggunakan dan melakukan revaluasi dalam pengukuran aset tetap pada perusahaan manufaktur sektor industri dasar dan kimia yang terdaftar di bursa efek indonesia maka digunakan nilai dari Nagelkerke R. Square.

Tabel 6Hasil Uji Koefisien Determinasi

\begin{tabular}{|l|r|r|r|}
\hline \multicolumn{3}{|c|}{ Model Summary } \\
Step & -2 Log likelihood & Cox \& Snell R Square & Nagelkerke R Square \\
\hline 1 & $8.100^{\mathrm{a}}$ & .231 & .351 \\
\hline
\end{tabular}

a. Estimation terminated at iteration number 6 because parameter estimates changed by less than .001 .

Sumber : Hasil Output SPSS

Tabel 6 menunjukkan bahwa nilai Nagelkerke R. Square sebesar 0,351 sedangkan nilai Cox \& Snell $\mathrm{R}$ Square sebesar 0,231. Hal ini menunjukkan bahwa keputusan perusahaan memilih untuk melakukan dan menggunakan revaluasi pada perusahaan manufaktur sektor industri dasar dan kimia yang terdaftar di Bursa Efek Indonesia dipengaruhi oleh intensitas aset tetap, leverage, likuiditas, pertumbuhan perusahaan dan ukuran perusahaan sebesar 35,1 \% sedangkan 64,9\% dipengaruhi oleh faktor-faktor lain yang tidak diteliti.

\section{Tabel Klasifikasi}

Tabel klasifikasi akan menunjukkan kekuatan prediksi dari model untuk memprediksi kemungkinan revaluasi aset tetap yang ditunjukkan pada tabel klasifikasi berikut : 
Tabel 7 Tabel Klasifikasi

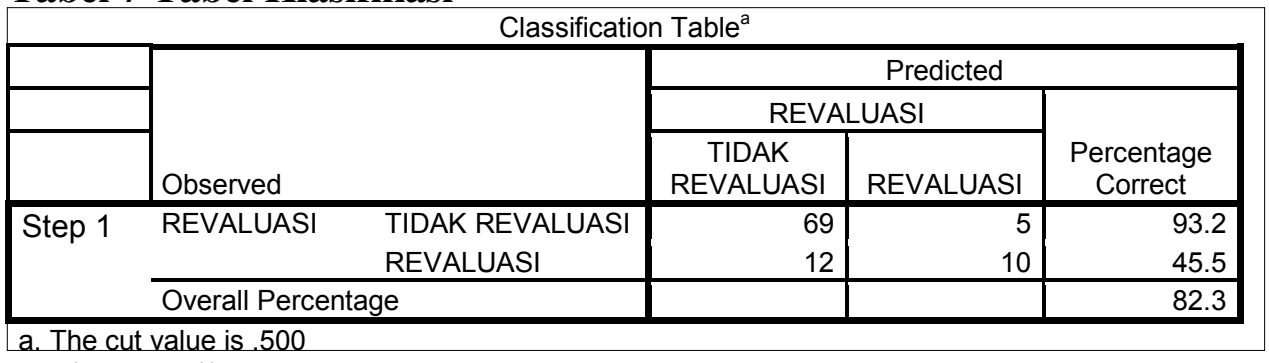

Sumber : Hasil Output SPSS

Berdasarkan tabel 7 dapat di simpulkan bahwa jumlah sampel yang tidak memilih untuk melakukan dan menggunakan revaluasi sebagai metode pencatatan dalam aset tetap perusahaannya adalah sebanyak 74 perusahaan. Dimana yang benar-benar tidak melakukan dan menggunakan revaluasi sebanyak 69 perusahaan dengan tingkat prediksi sebesar 93,2\% dapat diprediksi oleh model regresi dan yang seharusnya tidak memilih untuk melakukan dan menggunakan revaluasi namun melakukan dan menggunakannya sebanyak 5 perusahaan . Jumlah sampel yang memilih untuk melakukan dan menggunakan revaluasi sebagai metode pencatatan dalam aset tetap perusahaannya adalah sebanyak 22 perusahaan. Dimana yang benar-benar memilih untuk melakukan dan menggunakan revaluasi sebanyak 10 perusahaan dengan tingkat prediksi sebesar $45,5 \%$ dapat diprediksi oleh model regresi dan yang seharusnya memilih untuk melakukan dan menggunakan revaluasi namun tidak melakukan dan menggunakannya sebanyak 12 perusahaan. Nilai overall percentage sebesar $82,3 \%$ menunjukkan bahwa variabel bebas yang dimasukkan ke dalam model dapat digunakan untuk memprediksi keputusan untuk melakukan dan menggunakan revaluasi aset tetap dengan ketepatan estimasi $82,3 \%$.

\section{Hasil Uji Hipotesis}

Berdasarkan hasil perhitungan dengan menggunakan program SPSS ringkasan hasil pengujian dapat di lihat pada tabel berikut : 
Tabel 8 Hasil Uji Regresi Logistik

\begin{tabular}{|c|c|c|c|c|c|c|c|}
\hline \multicolumn{8}{|c|}{ Variables in the Equation } \\
\hline & & B & S.E. & Wald & Df & Sig. & $\operatorname{Exp}(B)$ \\
\hline \multirow[t]{6}{*}{ Step $1^{a}$} & $\mathrm{X} 1$ & -3.780 & 1.824 & 4.293 & 1 & .038 & .023 \\
\hline & $\mathrm{X} 2$ & .412 & .162 & 6.506 & 1 & .011 & 1.510 \\
\hline & X3 & -.189 & .318 & .352 & 1 & .553 & .828 \\
\hline & X4 & 2.287 & 1.076 & 4.516 & 1 & .034 & 9.848 \\
\hline & X5 & .373 & .220 & 2.866 & 1 & .090 & 1.452 \\
\hline & $\begin{array}{l}\text { Const } \\
\text { ant }\end{array}$ & -8.241 & 4.534 & 3.305 & 1 & .069 & .000 \\
\hline
\end{tabular}

a. Variable(s) entered on step 1: X1, X2, X3, X4, X5.

Sumber : Hasil Output SPSS

\section{Hasil Uji Regresi Logistik Secara Simultan}

Pengujian regresi logistik secara simultan pada penelitian ini dapat dilihat berdasarkan tabel Omnibus Tests of Model Coefficients. Tujuannya adalah untuk melihat pengaruh variabel bebas (intensitas aset tetap, leverage, likuiditas pertumbuhan perusahaan dan ukuran perusahaan,) secara bersama terhadap variabel terikat (revaluasi). Hasil pengujiannya adalah sebagai berikut:

\section{Tabel 9 Pengujian Regresi Logistik Secara Simultan}

Omnibus Tests of Model Coefficients

\begin{tabular}{|c|c|c|c|c|}
\hline & & Chi-square & Df & Sig. \\
\hline \multirow[t]{3}{*}{ Step 1} & Step & 25.247 & 5 & .000 \\
\hline & Block & 25.247 & 5 & .000 \\
\hline & Model & 25.247 & 5 & .000 \\
\hline
\end{tabular}

Sumber : Hasil Output SPSS

Berdasarkan tabel 9data secara simultan menunjukkan hasil signifikansi 0,000 lebih kecil dari $\alpha=0,05$. Hal ini berarti bahwa semua variabel independen berpengaruh secara bersama-sama terhadap revaluasi dalam pengukuran aset tetap. Hasil tersebut menjelaskan bahwa semua variabel independen jika diuji secara bersamaan dalam penelitian ini berpengaruh secara signifikan terhadap revaluasi dalam pengukuran aset tetap pada perusahaan manufaktur sektor industri dasar dan kimia yang terdaftar di BEI 2014-2017. 


\section{PEMBAHASAN}

\section{Pengaruh Intensitas Aset Tetap Terhadap Revaluasi Aset Tetap}

Hasil penelitian ini berdasarkan tabel uji regresi logistik (tabel 8) menunjukan bahwa variabel intensitas aset tetap memiliki nilai signifikansi sebesar $0,038<0,05$ dengan nilai $\operatorname{Exp}(\mathrm{B})$ sebesar 0,023 sehingga memiliki nilai koefesien negatif sebesar -3,780 (Logaritma Natural dari 0,023). Dari hasil tersebut dapat diperoleh kesimpulan bahwa variabel intensitas aset tetap berpengaruh negatif dan signifikan terhadap revaluasi aset tetap yang menunjukkan bahwa terjadi hubungan negatif antara intensitas aset tetap dengan revaluasi aset tetap dimana semakin besar nilai intensitas aset tetap maka kemungkinan untuk melakukan dan menggunakan revaluasi sebagai metode pengukuran setelah pengakuan awal aset tetap oleh suatu perusahaan semakin turun atau kecil.

Hasil uji penelitian ini mengalami perbedaan dengan teori Sartono (2016:248) yang mengatakan bahwaperusahaan dengan tingkat intensitas aset tetap yang besar/tinggi akan memilih untuk menggunakan metode pengukuran dan pengakuan aset tetap yang lebih mencerminkan nilai aset yang sesungguhnya yaitu melalui revaluasi aset tetap dan sebaliknya.Hal tersebut disebabkan oleh beberapa faktor yaitu besar kecilnya intensitas aset tetap tidak menjadi dasar pertimbanganmanajemen dalam melakukan tindakan oportunis yaitu melakukan dan menggunakan revaluasisebagai metode pengukuran aset tetap setelah pengakuan awalnya. Meskipun asettetap digunakan dalam sebagian besar operasional perusahaan, hal ini tidak menjadi pertimbangan bagi perusahaan dalam melakukan revaluasi aset tetap.Perusahaan manufaktur sektor industri dasar dan kimia yangterdaftar di BEI periode tahun 2014, 2015, 2016 dan 2017 memiliki intensitas aset tetapyang bervariasi dan berfluktuasi dari tahun ke tahun. Dimana sejumlah perusahaanmemiliki porsi aset tetap yang sangat rendah dan sebagian dari total sampel memiliki proporsi aset tetap yang sangat besar.

Selain itu, faktor lain yang menyebabkan intensitas tidak berpengaruh positif terhadap revaluasi aset tetap yaitu perusahaan dengan intensitas aset tetap besar, tanpa revaluasi pun sudah memiliki nilai aset tetap yang besar begitu juga perusahaan dengan intensitas aset tetap yang kecil juga tidak melakukan revaluasi aset tetap karena porsi aset tetap yang kecil tidak berpengaruh banyak pada asimetri informasi, sehingga revaluasi tidak terlalu penting untuk dilakukan. Bahkan tidak terlalu diperhatikan oleh stakeholder.Akibatnya, keputusan melakukan revaluasi aset tetap sulit diprediksi melalui intensitas aset tetap. Oleh karena itu pihak manajemen 
tidak mempertimbangkan proporsi aset tetap sebagai faktor yang mempengaruhi keputusan melakukan revaluasi aset tetap. Hasil penelitian ini sejalan dengan penelitian yang dilakukan oleh Seng dan $\mathrm{Su}$ (2010) dan Khairati (2015) yang juga menemukan tidak adanya pengaruh intensitas aset tetap terhadap revaluasi aset tetap.

\section{PengaruhLeverage Terhadap Revaluai Aset Tetap}

Leverage menggambarkan posisi utang terhadap aset ataupun ekuitas. Debt ratio digunakan untuk mengukur variabel leverage yaitu dengan membagi total utang dengan total asetnya. Hasil penelitian ini berdasarkan tabel uji regresi logistik (tabel 8) menunjukan bahwa variabel leverage memilikinilai signifikansi sebesar $0,011<0,05$ dengan nilai $\operatorname{Exp}(B)$ sebesar 1,510 sehingga memiliki nilai koefesien positif sebesar 0,412 (Logaritma Natural dari 1,510). Dari hasil tersebut dapat diperoleh kesimpulan variabel leverage berpengaruh positif dan signifikan terhadap revaluasi aset tetap yang menunjukkan bahwa terjadi hubungan positif antara leveragedengan revaluasi aset tetap dimana semakin tinggi leveragemaka kemungkinan perusahaan untuk melakukan dan menggunakan revaluasi sebagai metode pengukuran setelah pengakuan awal aset tetapnya akan meningkat.

Hasil uji penelitianini sesuai dengan teori Kasmir (2011:113) yang mengatakan bahwa perusahaan dengan tingkat leverage yang tinggi akan menggunakan revaluasi aset tetap dan sebaliknya. Maka dari itu, manajemen memilih melakukan dan menggunakan revaluasi aset tetap daripada metode biaya terkait motivasinya menurunkan leverage, sehingga meningkatkan kelayakan perusahaan di hadapan kreditur. Rasio leverage yang menurun akan memperbaiki reputasi finansial perusahaan di mata kreditur. Kreditur merasa lebih yakin dan mau memberikan kapasitas pinjaman yang lebih besar. Sehingga pemasukan dana dari utang bisa lebih mudah karena dengan revaluasi aset tetap akan membantu perusahaan dengan kebutuhan modal utang yang tinggi, untuk memperkuat posisi keuangan mereka dan memperkuat prospek pertumbuhan mereka. Sehingga perusahaan dapat berekspansi dan membiayai proyek-proyek yang menguntungkan perusahaan. Hasil ini sejalan dengan penelitian yang dilakukan oleh Lin dan Peasnell (2000), Missonier-Piera (2007), Seng dan $\mathrm{Su}$ (2010) dan Manihuruk (2015) yang juga menemukan adanya pengaruh leverage terhadap revaluasi aset tetap. 


\section{Pengaruh Likuiditas Terhadap Revaluasi Aset Tetap}

Hasil penelitian ini berdasarkan uji regresi logistik (tabel 8) menunjukkan likuiditas tidak signifikan secara statistik karena nilai signifikansinya yaitu $0,553>0,05$ dengan nilai $\operatorname{Exp}(B)$ sebesar 0,828 sehingga memiliki nilai koefesien negatif sebesar -0,189 (Logaritma Natural dari 0,828 ). Dari hasil tersebut dapat diperoleh kesimpulan bahwa variabel likuiditas berpengaruh negatif dan tidak signifikan terhadap revaluasi aset tetap yang menunjukkan bahwa tidak adanya pengaruh likuiditas terhadap kebijakan perusahaan untuk melakukan revaluasi aset tetap.Hasil ini berbeda dengan teori mengatakan bahwa perusahaan dengan tingkat likuiditas yang rendah akan menggunakan revaluasi aset tetap dan sebaliknya (Kasmir, 2011:110).

Likuiditas tidak mempengaruhi keputusan untuk melakukan revaluasididuga karena manajemen ragu dengan manfaat dari revaluasi aset tetap.Meskipun revaluasi menginformasikan nilai wajar aset tetap yangmerepresentasikan sejumlah kas yang akan diterima, informasi tersebut kurangberguna selama aset tetap tersebut tidak dalam posisi akan dijual. Karenakebijakan revaluasi memang tidak memiliki dampak nyata terhadap arus kasperusahaan. Saat mengetahui likuidiatas rendah, manajemen mungkin lebih berpikir untuk lebih memprioritaskan kebijakan yang berdampak langsung padakas/aset lancar sehingga dapat memperbaiki likuiditas misalnya, fokus pada manajemen piutang dan pengelolaan persediaan.

Walaupun beberapa peneliti sebelumnya yang dilakukan oleh Tay (2009) dan Manihuruk (2015) menemukan adanya hubungan antara likuiditas dengan revaluasi aset tetap, tetapi hasil ini sejalandengan penelitian yang dilakukan oleh Sihombing (2017) yang juga tidak menemukan adanya pengaruh likuiditas terhadap revaluasi aset tetap.

\section{Pengaruh Pertumbuhan Perusahaan Terhadap Revaluasi Aset Tetap}

Hasil penelitian ini berdasarkan uji regresi logistik (tabel 8) menunjukan bahwa pertumbuhan perusahaan memiliki nilai signifikansi sebesar 0,034<0,05 dengan nilai $\operatorname{Exp(B)~sebesar~9,848~sehingga~memiliki~}$ nilai koefesien positif sebesar 2,287 (Logaritma Natural dari 9,848 ).Dari hasil tersebut dapat diperoleh kesimpulan bahwa variabel pertumbuhan perusahaan berpengaruh positif dan signifikan terhadap revaluasi aset tetap yang menunjukkan terjadi hubungan positif antara pertumbuhan perusahaan dengan revaluasi aset tetap (Y) dimana semakin tinggi tingkat pertumbuhan perusahaan maka kemungkinan perusahaan untuk melakukan 
dan menggunakan revaluasi aset tetap sebagai metode pengukuran setelah pengakuan awal aset tetap akan meningkat.Hasil uji penelitian ini sesuai dengan teori yang mengatakan bahwa perusahaan dengan tingkat pertumbuhan yang tinggi akan memilih untuk menggunakan revaluasi aset tetap dan sebaliknya (Sartono, 2016:248).

Karena perusahaan dalam kondisi tumbuh berada dalam kondisi memerlukan sumberdaya finansial untuk membiayai aktivitasnya, meluaskan cakupan bisnis dan membiayai proyek-proyek yang menguntungkan. Pertumbuhan perusahaan mendorong manajemen untuk merevaluasi aset tetapnya sebagai sarana mengkomunikasikan informasi nilai wajar kepada stakeholder. Revaluasi bertujuan untuk memberikan informasi nilaisesungguhnya dari aset tetap, sehingga kreditur tahu berapa nilai terkini dari aset tetap yang bisa dijadikan jaminan utangnya. Walaupun beberapa peneliti sebelumnya yang dilakukan oleh Seng dan Su (2010) tidak menemukan adanya hubungan antara pertumbuhan perusahaan dengan revaluasi aset tetap, tetapi hasil penelitian ini sesuaidengan penelitian yang dilakukan oleh Sihombing (2017).

\section{Pengaruh Ukuran Perusahaan Terhadap Revaluasi Aset Tetap}

Hasil penelitian ini berdasarkan uji regresi logistik (tabel 8), menunjukan bahwa ukuran perusahaan memiliki nilai signifikansi sebesar $0,090>0,05$ dengan nilai $\operatorname{Exp}(\mathrm{B})$ sebesar 1,452 sehingga memiliki nilai koefesien positif sebesar 0,373 (Logaritma Natural dari 1,452).Dari hasil tersebut dapat diperoleh kesimpulan bahwa variabel ukuran perusahaan yang diproksikan dengan Ln total aset berpengaruh positif dan tidak signifikn terhadap revaluasi aset tetap yang menunjukkan bahwa tidak adanya pengaruh ukuran perusahaan terhadap kebijakan perusahaan untuk melakukan revaluasi aset tetap.

Hasil ini mengalami perbedan dengan teori Sartono (2016:249) yangmengatakan bahwa perusahaan dengan ukuran perusahaan yang tinggi akan menggunakan revaluasi aset tetap dan sebaliknya.Variabel ukuran perusahaan tidak berpengaruh signifikan terhadap keputusan melakukan revaluasi aset tetap juga dapat disebabkan karena besar kecilnya penjualan tidak serta merta membuat perusahaan ingin memperkecil labayang dilaporkan seperti diprediksi oleh hipotesis biaya politis dalam teori akuntansi positif. Manajemen berpikir untuk melaporkan laba secara apa adanyabaik itu laba yang tinggi atau rendah sebagai upaya transparansi kepada publik.Oleh karena itu pihak manajemen tidak mempertimbangkan 
ukuran perusahaansebagai faktor yang mempengaruhi keputusan melakukan revaluasi aset tetap.

Walaupun beberapa peneliti sebelumnya yang dilakukan oleh Lin dan Peasnell (2000), Tay (2009) dan Seng dan Su (2010) menemukan adanya hubungan antara ukuran perusahaan dengan revaluasi aset tetap, tetapi hasil penelitian ini sesuai dengan penelitian yang dilakukan oleh Manihuruk (2015), Khairati (2015) dan Sihombing (2017) yang juga tidak menemukan adanya pengaruh ukuran perusahaan terhadap revaluasi aset tetap.

Pengaruh intensitas aset tetap, leverage, likuiditas, pertumbuhan perusahaan dan ukuran perusahaan terhadap revaluasi aset tetap

Penelitian ini bertujuan untuk menguji probabilitas kemungkinan pengaruh intensitas aset tetap, leverage, likuiditas, pertumbuhan perusahaan dan ukuran perusahaan secara bersama-sama terhadap keputusan untuk melakukan dan menggunakan revaluasi sebagai kebijakan pengukuran setelah pengakuan awal aset tetap. Hasil pengujian regresi logistik menunjukkan bahwa variabel intensitas aset tetap, leverage, likuiditas, pertumbuhan perusahaan dan ukuran perusahaan berpengaruh secara simultan terhadap revaluasi aset tetap.

Hal ini dapat dilihat dari hasil uji hipotesis (tabel 9)yang mana nilai intensitas aset tetap, leverage, likuiditas, pertumbuhan perusahaan dan ukuran perusahaan memiliki nilai Chi- Square 25,247 > X2 tabel pada DF 5 (jumlah variabel independen 5) yaitu sebesar 11,070 atau dengan tingkat signifikansi sebesar 0,000 yang lebih kecil dibandingkan dengan taraf signifikansi $(0,05)$ sehingga menunjukkan bahwa penambahan variabel independen dapat memberikan pengaruh nyata terhadap model, atau dengan kata lain model dinyatakan fit dengan tingkat signifikan pada 0,000yang lebih kecil dibandingkan taraf signifikansi $(0,05)$.Meskipun dilihat dari nilai, pengaruh dari intensitas aset tetap, leverage, likuiditas, pertumbuhan perusahaan dan ukuran perusahaanhanya sebesar $35,1 \%$. Ini berarti bahwa masih banyak faktor lain (yaitu sebesar 64,9 \%) yang tidak diteliti dalam penelitian ini yang dapat mempengaruhi revaluasi dalam pengukuran aset tetap. 


\section{KESIMPULAN DAN SARAN}

\section{Kesimpulan}

Berdasarkan hasil pengujian dan pembahasan yang telah dijelaskan pada bagian sebelumnya, maka dapat disimpulkan bahwa:

1. Intensitas aset tetap berpengaruh negatif dan signifikan terhadap keputusan perusahaan untuk melakukan dan menggunakan revaluasi aset tetap pada perusahaan manufaktur sektor industri dasar dan kimia yang terdaftar di Bursa Efek tahun 2014-2017.

2. Leverage berpengaruh positif dan signifikan terhadap keputusan perusahaan untuk melakukan dan menggunakan revaluasi aset tetap pada perusahaan manufaktur sektor industri dasar dan kimia yang terdaftar di Bursa Efek Indonesia tahun 2014-2017.

3. Likuiditas berpengaruh negatif dan tidak signifikan terhadap keputusan perusahaan untuk melakukan dan menggunakan revaluasi aset pada perusahaan manufaktur sektor industri dasar dan kimia yang terdaftar di Bursa Efek Indonesia tahun 2014-2017.

4. Pertumbuhan perusahaan berpengaruh positif dan signifikan terhadap keputusan perusahaan untuk melakukan dan menggunakan revaluasi aset tetap pada perusahaan manufaktur sektor industri dasar dan kimia yang terdaftar di Bursa Efek Indonesia tahun 2014-2017.

5. Ukuran perusahaan berpengaruh positif dan tidak signifikan terhadap keputusan perusahaan untuk melakukan dan menggunakan revaluasi aset tetap pada perusahaan manufaktur sektor industri dasar dan kimia yang terdaftar di Bursa Efek Indonesia tahun 2014-2017.

6. Intensitas aset tetap, leverage, likuiditas, pertumbuhan perusahaan dan ukuran perusahaan berpengaruh positif dan signifikan secara bersamasama terhadap keputusan perusahaan untuk melakukan dan menggunakan revaluasi aset tetap pada perusahaan manufaktur sektor industri dasar dan kimia yang terdaftar di Bursa Efek Indonesia tahun 2014-2017.

\section{Saran}

Berdasarkan hasil penelitian dan keterbatasan peneliti terdapat beberapa saran untuk penelitian selanjutnya, yaitu:

1. Penelitian selanjutnya dapat mempertimbangkan untuk menggunakan sektor lainnya sebagai objek penelitian. 
2. Penelitian selanjutnya dapat menambah atau mengganti variabelvariabel bebas lainnya yang dapat mengembangkan penelitian mengenai revaluasi aset tetap.

3. Penelitian selanjutnya dapat memperpanjang periode penelitian sehingga dapat melihat kecendrungan yang terjadi dalam jangka panjang sehingga hasil yang diperoleh akan lebih dapat digeneralisasi dan akan lebih menggambarkan kondisi sesungguhnya selama jangka panjang.

\section{DAFTAR PUSTAKA}

Brigham, Eugene F. \& Joel F.Houston. 2010. Dasar-Dasar Manajemen Keuangan. Jakarta: Salemba Empat.

Ghozali, Imam. 2018. Aplikasi Analisis Multivariate dengan Program IBM SPSS 25.Semarang: Badan Penerbit Universitas Diponegoro.

Harahap, Sofyan Syafri. 2018. Teori akuntansi Edisi Revisi 2011. Jakarta: PT Raja Grafindo Persada.

Ikatan Akuntansi Indonesia (IAI). 2018. Standar Akuntansi Keuangan (SAK). Jakarta: Salemba Empat.

Kasmir. 2011. Analisis Laporan Keuangan. Jakarta: PT Raja Grafindo Persada.

Khairati, Adzkya. 2015. Pengaruh Leverage, Firm Size dan Fixed Asset Intensity

terhadap Keputusan Perusahaan Melakukan Revaluasi Aset Tetap.Skripsi.Universitas Bung Hatta, Padang.

Lin, Y. C dan K. V Peasnell, 2000a. Asset Revaluation and Current Cost Accounting: UK Corporate Disclosure Decision in 1983.British Accounting Review, 32.

Manihuruk, Tunggul Natalius H. \& Aria Farahmita.2015. Analisis Faktorfaktor yang Mempengaruhi Pemilihan Metode Revaluasi Aset Tetap pada Perusahaan yang Terdaftar di Bursa Saham Beberapa Negara ASEAN.Simposium Nasional Akuntansi 18Universitas Sumatera Utara, Medan 16-19September 2015.

Missonier-Piera, F. (2007). Motives for fixed-asset revaluation: An empirical analysis with Swiss data. Journal of Business Finance and Accounting, 34, 1025 - 1050.

Murti, Wahyu. 2011. Pengaruh Kinerja Keuangan Terhadap Return Saham. Jakarta: Cintya Press. 
Riyanto,Bambang.2001. Dasar-Dasar

PembelanjaanPerusahaan. Yogyakarta: Gajah Mada University Press.

Rudianto.2012. Akuntansi Pengantar. Jakarta: Penerbit Erlangga.

Sartono, Agus. 2016. Manajemen Keuangan Teori Dan Aplikasi. Yogyakarta: BPFE-Yogyakarta.

Seng, Dyna \& Jiahua Su. 2010. Managerial Incentives Behind Fixed Asset Revaluation. International Journal of Business Research, Vol 10 (2).

Sihombing, Rohana L. 2017. Analisis Faktor-Faktor Yang Mempengaruhi Dipilihnya Model Revaluasi Dalam Pengukuran Aset Tetap Pada Perusahaan Manufaktur Yang Terdaftar Di BEI. Skripsi. Universitas Sumatera Utara, Medan.

Sumarsan, Thomas. 2018. Akuntansi Dasar Dan Aplikasi Dalam Bisnis Versi IFRS. Jakarta: PT Indeks.

Syamsuddin, Lukman. 2009. Manajemen Keuangan Perusahaan: Konsep Aplikasi dalam: Perencanaan, Pengawasan, dan Pengambilan Keputusan. Jakarta: Rajawali Pers.

Tay, Ink. 2009. Fixed Asset Revaluation:Management Incentives and MarketReactions. Thesis. Canterbury: Lincoln Univeristy. 